\title{
Water Quality Assessment of Iju River in Ogun State, Nigeria: Effect of Human Activities
}

\author{
$*{ }^{1}$ Mutiu A. Alabi, ${ }^{2}$ Gbolahan Idowu, ${ }^{3}$ Oluwaseyi A. Osoteku, ${ }^{1}$ Folashade H. \\ Fasuyi, ${ }^{1}$ Yetunde A, Adeyemi, ${ }^{4}$ Taofeeq A. Adedokun and \\ ${ }^{5}$ Adelowo A. Adebiyi \\ ${ }^{1}$ Molecular Biology/Bioinformatics Unit, Bioresources Development Centre, National Biotechnology \\ Development Agency, Ogbomosho, Nigeria. \\ ${ }_{2}^{2}$ Physiology Department, Obafemi Awolowo College of Health Sciences, Faculty of Basic Medical Sciences, \\ Olabisi Onabanjo University, Ago-Iwoye, Nigeria. \\ ${ }^{3}$ Department of Science Laboratory Technology, School of Pure and Applied Sciences, Gateway Polytechnic, \\ Saapade, Nigeria. \\ ${ }^{4}$ Biochemistry Department, Faculty of Science, Ben Carson School of Medicine, \\ Babcock University, Ilishan, Nigeria \\ ${ }^{5}$ Biochemistry Department, Obafemi Awolowo College of Health Sciences, Faculty of Basic Medical Sciences, \\ Olabisi Onabanjo University, Ago-Iwoye, Nigeria.
}

\begin{abstract}
Water is essential and vital to all human activities. Despite its importance, it is the most poorly managed resources in the world. In most towns in Ogun State, South West, Nigeria, access to clean and portable water is a challenge, resulting in water borne diseases. The research aims at accessing the level of influence of human activities on the physical and chemical properties of Iju River, Iju town in Ogun State, South West Nigeria. Water samples were collected from Point 1, 2 and 3 (down-stream, mid-stream and up-stream respectively) from Iju river and the following parameter were determined: $p H$,electrical conductivity (EC), total suspended solid (TSS), total solid (TS), total acidity, total alkalinity, total hardness, chloride, nitrate, phosphate, sulphate, iron, dissolved oxygen (DO), biological oxygen demand (BOD) and chemical oxygen demand (COD). Levels of EC, TS, and BOD at the mid-stream and the iron level at down-stream, mid-stream and up-stream are higher than WHO standards. The high concentration of iron in the entire samples suggests that the river water used for irrigation of vegetable and high level of BOD makes the water unsuitable for aquatic life and human consumption.Relevant agencies should make continuous effort to control, regulate and educate the people and those using the water on indiscriminate waste disposal from laundry, domestic and agriculture within the study area.
\end{abstract}

Keyword: River, pollution, biological oxygen demand, laundry.

\section{Introduction}

Toxicity and sub-lethal toxicity of soaps, detergents and bio-refractory organics create water pollution and affect the ecology and micro-organism, fauna and flora near the pollution load [1,2]. Biological toxic effect is significant to physiology and behaviour of organism to alter its capacity for growth and reproduction or mortality $[3,4]$. Hence soaps, detergents and bio-refractory organics containing water should be avoided to drain in the water reservoir the check the pollution.

Despite these improvements, continuing urban growth and nonpoint-source runoff of contaminants and storm water are expected to challenge these historic gains $[5,6]$. Though, water is essential to all forms of life and makes up 50 to $97 \%$ of the weight of all plants and animals and about $70 \%$ of human body $[7,8]$. Despite its importance, water is the most poorly managed resource in the world $[9,10]$. Urbanisation is known to impact the hydrology and aquatic integrity of urban streams. Native aquatic insect communities become less abundant and diverse in streams impacted by urbanisation $[11,12]$. Iju river is the primary sources of drinking water in Iju township. The river receives laundry detergent, urban runoff, agricultural waste and sewage discharge and is an area of rapid growth in urban sprawl.

Interest in metals like iron $(\mathrm{Fe})$ which is required for metabolic activity in organisms, lies in the narrow 'window' between their essentiality and toxicity $[13,14,15]$. Their sources are mainly from weathering of minerals and soils, atmospheric deposition [16,17]; domestic effluents [11,18]; urban runoff $[4,18]$ and spoil heap [8]. It is toxic at very low concentration in water and is known to cause brain damage in mammals $[5,19]$.

The major effect of the presence of $\mathrm{Fe}$ in domestic water is aesthetic because of the colour. The $\mathrm{pH}$ of a water body determines the chemical species of many metals and thereby alters the availability and toxicity in the aquatic environment $[5,14]$. This catchment supports a rapidly growing population and there are concerns 
regarding the water quality of the river. The main uses of water in the catchments are domestic, agricultural (i.e. livestock watering) and aquatic ecosystem use [10].

The research work is aimed at determining the influence of human activities on the physical and chemical properties of Iju river of Ogun State, South West Nigeria. The outcome of this research could be beneficial Local, State, and Federal Governments as it will be useful in policy formulation, implementation, monitoring and evaluation, especially on issues relating to water and sanitation management.

\section{Reagents and Chemicals}

\section{Materials And Methods}

Erichrome black-T, ammonium chloride $\left(\mathrm{NH}_{4} \mathrm{Cl}\right)$, magnesium sulphate pentahydrate $\left(\mathrm{MgSO}_{4}\right)$, sodium iodide (NaI), sodium azide, chloroform, potassium dihydrogen phosphate $\left(\mathrm{KH}_{2} \mathrm{PO}_{4}\right)$, hydrochloric acid $(\mathrm{HCl})$, barium chloride $(\mathrm{BaCl})$, silver nitrate $\left(\mathrm{AgNO}_{3}\right)$, sodium hydroxide $(\mathrm{NaOH})$, methyl orange and phenolphthalein were purchased from May and Baker, England. Sodium thiosulphate $\left(\mathrm{Na}_{2} \mathrm{SO}_{3}\right)$, starch indicator, potassium dichromate $\left(\mathrm{K}_{2} \mathrm{Cr}_{2} \mathrm{O}_{7}\right)$, ferroin indicator, standard FAS (ferrous ammonium sulphate), molybdenum reagents and anti-bumping granules were products of Pharmacia Fine Chemicals, Uppsala, Sweden. All reagents were of analytical grade.

\section{Sampling Protocol}

Three rivers (Majopa, Iju and Ilaro rivers) were selected and from each river three water samples were taken from three sampling points namely point 1,2 and 3 as recommended by Morrison et al. [1] and Kumar [20]. Points 1 and 3 are non-pollutant contact points (downstream and upstream) while point 2 is the pollutant contact point (mid stream) very close to the human activities going on in the area. Containers were lowered to approximately $20 \mathrm{~cm}$ below water surface with the neck pointing slightly down, as suggested by Bartram and Balanc [21]. The labelled containers were kept at temperature of $5^{\circ} \mathrm{C}$ until analysis not later than 24 hours.

\section{Physical and Chemical Tests}

The procedure in sampling for river water involves two basic steps; these are information on physical and chemical properties. Water quality parameters analyzed in accordance to standard methods of APHA [22] were the physical properties which include: $\mathrm{pH}$ and electrical conductivity while chemical properties were total suspended solid, total solid, total acidity, total alkalinity, total hardness, chloride, nitrate, phosphate, sulphate, iron, dissolved oxygen, biological oxygen demand and chemical oxygen demand.

\section{Quality Assurance Procedures}

Special precautions taken for quality assurance were as follows; all reagents were of analytical grade and samples for metal analysis were preserved with $3 \mathrm{ml}$ concentrated $\mathrm{HNO}_{3}$ per liter in the field. Samples used for determination of metals, physical properties, $\mathrm{SO}_{4}{ }^{2-}$ and $\mathrm{NO}_{3}{ }^{-}$were collected in plastic bottles and those for the determination of DO, COD, BOD and $\mathrm{PO}_{4}{ }^{3-}$ were collected in specialized glassware. Samples for DO were treated at the site with $2 \mathrm{ml}$ of manganese sulphate and $2 \mathrm{ml}$ alkaline-iodide-azide solution. Precautions were taken to avoid the trapping of atmospheric oxygen. Quality control measures for pollutants, especially toxic metals include reagent and blank analyses, spiked sample recovery determinations and multiplicity of samples.

Samples for $\mathrm{COD}, \mathrm{NO}_{3}^{-}, \mathrm{SO}_{4}^{2-}$ and $\mathrm{PO}_{4}^{3-}$ were refrigerated and analyzed within 24 hours. All plastics and glass wares utilized were pre-washed with detergent water solution, rinsed with tap water and soaked for 48 $\mathrm{h}$ in $50 \% \mathrm{HNO}_{3}$, then rinsed thoroughly with distilled deionized water. They were then air-dried in a dust free environment. All containers for bacteriological analysis, in addition to the previous treatments, were sterilized in an autoclave at $121^{\circ} \mathrm{C}$ for 15 minutes. The plastic bottles were not capped to avoid distortion. 


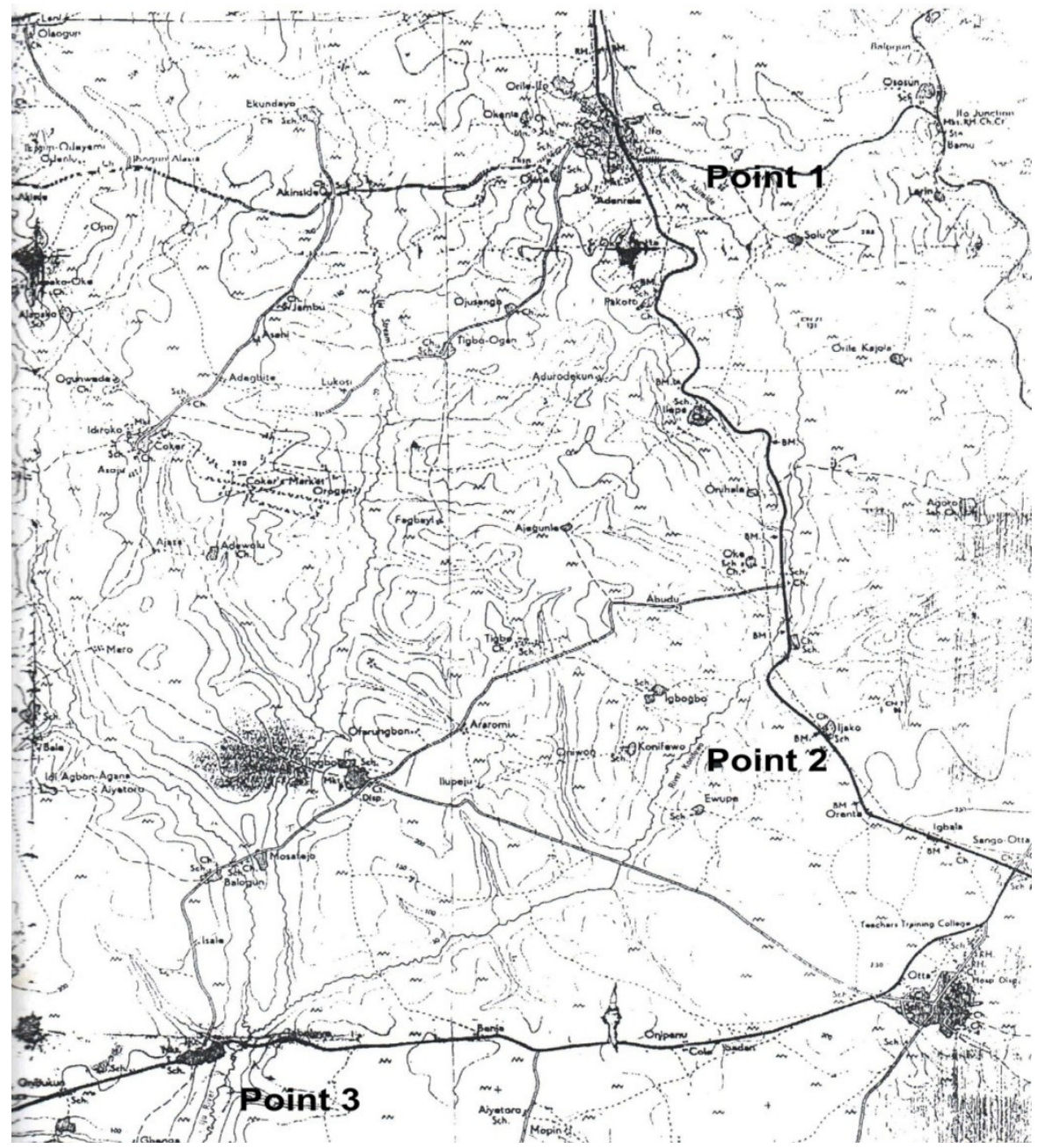

Figure 1: Showing the Iju River and the three collection points.

III. Results

Table 1. River Iju Physical and Chemical Properties

\begin{tabular}{|c|c|c|c|c|c|}
\hline & \multicolumn{3}{|c|}{ Sample Points } & \multicolumn{2}{|c|}{ Standards } \\
\hline Properties & Point 1 & Point 2 & Point 3 & WHO & FEPA \\
\hline $\mathrm{EC}(\mu \mathrm{S} / \mathrm{cm})$ & 436 & 1100 & 737 & $<1000$ & - \\
\hline Total Solid (mg/l) & 129 & 10467 & 69 & 1000 & - \\
\hline Total Alkalinity (mg/l) & 50 & 50 & 70 & $80-120$ & - \\
\hline Total Acidity (mg/l) & 6 & 10 & 6 & - & - \\
\hline Nitrate $(\mathrm{mg} / \mathrm{l})$ & 2.2 & 0.5 & 0.9 & 45 & 10 \\
\hline Phosphate (mg/l) & 2.67 & 4.01 & 3.18 & - & $>50$ \\
\hline Sulphate $(\mathrm{mg} / \mathrm{l})$ & 4 & 27 & 24 & 400 & 500 \\
\hline Iron $(\mathrm{mg} / \mathrm{l})$ & 1.03 & 2.21 & 1.74 & 0.3 & 0.3 \\
\hline DO (mg/l) & 3.01 & 3.05 & 2.85 & $5-8$ & 7.5 \\
\hline $\mathrm{BOD}(\mathrm{mg} / \mathrm{l})$ & 3 & 43.8 & 15 & 20 & - \\
\hline
\end{tabular}

Table 1 shows the physical and chemical properties of River Iju, Iju town in comparison with World Health Organisation [23] and Federal Environmental Protection Agency [24] standards.

\section{Discussion}

According to WHO [23] and FEPA standards [24], the optimal range of water pH for most of the aquatic species is from 6.5 to 8.5 . $\mathrm{pH}$ values of the sample water were within the optimal range and these values are within limit. Though, the upstream (point 3 ) is somewhat higher. The results of the analysis indicated that the electrical conductivity values obtained during the study ranged between 426 and $1100 \mu \mathrm{S} / \mathrm{cm}$. This shows 
that the values of both the downstream and upstream (Point 1 and 3) are within the desirable limits set by WHO standards except for the midstream point (Point 2) which is slightly higher than the WHO standard [16,23].

The results obtained in the analysis indicate that total suspended solid (TSS) is between 13 and $55 \mathrm{mg} / 1$ and above the desirable limits set by FEPA standards $(>10 \mathrm{mg} / \mathrm{l})$ with range of values. Also, the total solid values obtained during the study ranged between 69 and $10467 \mathrm{mg} / \mathrm{l}$. This shows that the values of the downstream and upstream (Point 1 and 3) are within the desirable limits set by WHO standards except for the midstream point (Point 2) is higher than the WHO standard [23]. Literature classified water TSS as follows: TSS less than $100 \mathrm{mg} / \mathrm{l}$ as weak, TSS greater than $100 \mathrm{mg} / 1$ but less than $220 \mathrm{mg} / \mathrm{l}$ as medium and TSS greater than $220 \mathrm{mg} / \mathrm{l}$ as strong water. Results of the study show that midstream point (Point 2) can be classified as strong.

Total alkalinity values obtained is within range of values between 50 and $70 \mathrm{mg} / \mathrm{l}$ and fall within the WHO standard [23] of 80-120 mg/l considered optimum for alkalinity of the water. Therefore, it was found that the amount of total alkalinity (Table 1) was running below the lower limit of optimum range. That might allow for rapid $\mathrm{pH}$ fluctuations, makes $\mathrm{pH}$ control more difficult and might contribute to corrosion. Total acidity results obtained in the analysis is within range of values between 6 and $10 \mathrm{mg} / \mathrm{l}$.

The concentrations of nitrate, sulphate and phosphate in all the sampling points varied between 0.5 to $2.2 \mathrm{mg} / 1$ for nitrate; 4 to $27 \mathrm{mg} / 1$ for sulphate and 2.67 to $4.01 \mathrm{mg} / \mathrm{l}$ for phosphate respectively (Table 1). Nitrate, sulphate and phosphate concentrations observed were below WHO [23] and FEPA [24] standards. The levels of nitrate may give rise to methaemoglobinemia, also the levels of nitrate reported in this study in addition to phosphate levels can cause eutrophication and may pose a problem for other uses.

The maximum acceptable concentration of iron in water for river water is $0.3 \mathrm{mg} / \mathrm{l}$ (WHO, 2004). Therefore, it was found that the level of iron obtained in the river water was from 1.03 to $2.21 \mathrm{mg} / \mathrm{l}$.

Dissolved oxygen (DO) values obtained for point 1 to 3 varied between 2.85 to $3.05 \mathrm{mg} / 1$ as shown in Table 1. The DO is a measure of the degree of pollution by organic matter, the destruction of organic substances as well as the self purification capacity of the water body. The WHO standard [23] for sustaining aquatic life is stipulated at $5 \mathrm{mg} / 1$ a concentration below this value adversely affects aquatic biological life [9], while concentration below $2 \mathrm{mg} / 1$ may lead to death for most fishes [25] and anaerobic conditions that cause bad odors [11]. The DO level at point 1 to 3 was below these levels.

An indication of organic oxygen demand content of river water can be obtained by measuring the amount of oxygen required for its stabilization either as BOD and COD. Biological Oxygen demand (BOD) is the measure of the oxygen required by microorganisms whilst breaking down organic matter. While Chemical Oxygen Demand (COD) is the measure of amount of oxygen required by both potassium dichromate and concentrated sulphuric acid to breakdown both organic and inorganic matters. BOD and COD concentrations of the river water were measured, as the two were important in unit process design.

BOD concentration of the river water obtained for point 1 to 3 ranged between 3 to $43.8 \mathrm{mg} / \mathrm{l}$ (Table 1). The concentrations of BOD at the mid stream (Point 2) were higher than the WHO standards [23] of $20 \mathrm{mg} / \mathrm{l}$ for river water. BOD indicates the presence of microbial activities and dead organic matter on which microbes can feed. BOD is directly linked with decomposition of dead organic matter present in the wastewater and hence the higher values of BOD can be directly related with pollution status of the wastewater [25]. The higher value of BOD means present of more biodegradable organic material [27].

The river water has an average COD concentration of 21 to $175 \mathrm{mg} / \mathrm{l}$ for point 1 to 3 (Table 1). The concentrations of COD at the mid stream (Point 2) were higher than the WHO standards (WHO, 2004) of $100 \mathrm{mg} / \mathrm{l}$ for river water. Chemical oxygen demand is defined as the amount of a specified oxidant that reacts with the samples under controlled conditions [28] and is often used as a measurement of pollutants in wastewater and natural water. COD of samples was not found in limit prescribed by WHO [23].

High COD and BOD concentration observed in the river water might be due to the use of chemicals, which are organic or inorganic that are oxygen demand in nature.

\section{Conclusion}

Based on the findings of the study, it could ascertained that there is evidence of both biological and chemical pollution, because of the importance of river water as a source of drinking water to the community and its use for domestic purposes, the best way to guarantee continued supplies of clean river water is to reduce pollution. Government should inform and educate the farmers about voluntary actions through which the farmer about voluntary actions through which the farmers can better manage animal waste, apply fertilizers and pesticides according to plant needs and properly schedule irrigation.

Individuals can help by improving their house keeping practices, by learning how to properly dispose of household products containing hazardous substances. Proper safety measures should be taken by individuals by not situating their wells along the flow path of potential pollution sources such as septic tanks, latrines and waste disposal sites and by disposing their laundry water. 


\section{References}

[1]. Morrison, G. O., Fatoki, O.S and Ekberg, A. (2001) Assessment of the impact of point source pollution from the Keiskammahoek sewage treatment plant on the keiskamma river. Water. SA., 27: 475-480.

[2]. Liu, W.H., Zhao, J.Z., Ouyang, Z.Y., Soderlund, L. and Liu, G.H. (2005). Impacts of sewage irrigation on heavy metals distribution and contamination in Beijing, China. Environ. Int. J. 31: 805-812.

[3]. Griego, J R., Del-valle, F R. and Clason, D (2003). Industrial wastewater treatment case studies of twoefood processing plants located in southern New Mexico, 2003 IFT Annual Meeting, Chicago, www.ift.confex.com.

[4]. Anikwe, M.A.N. and Nwobodo, K.C.A. (2006). Long term effect of municipal waste disposal on soil properties and productivity of sites used for urban agriculture in Abakaliki, Nigeria. Bioresources Technol. 83, 241-251.

[5]. Muchuweti, M.J., Birkett, J.W., Chinyanga, E., Zvauya, R., Scrimshaw, M.D., and Lester, J.N. (2006). Heavy metal content of vegetables irrigated with mixture of wastewater and sewage sludge in Zimbabwe: Implications for human health. Agric. Ecosyst. Environ. 112: 41-48.

[6]. Ogugbuaja, V.O. and Kinjir, R. (2001). Determination of aqueous pollutants in Rivers Gongola, Benue and Kiri Dam in Adamawa State-Nigeria. Res. J. Sci. 7(1-2):1-6.

[7]. Rene, E.R. and Saidutta, M.B. (2008). Prediction of Water Quality Indices by Regression Analysis and Artificial Neural Networks. Int. J. Environ. Res. 2(2): 183-188.

[8]. Bariweni, P. A., Izonfuo, W. A. L. and Amadi, E. N. (2000). An assessment of domestic waste levels and their current management strategies in Yenagoa metropolis. Global J. Pur. Appl. Sci. 38, 129-136.

[9]. Rao, S.N. (2006). Seasonal variation of groundwater quality in a part of Guntur District andhra Pradesh, India. Environ Geol., 49: 413-429.

[10]. Izonfuo, L.W.A. and Bareweni, A.P. (2001). The effects of Urban Runoff Water and Human Activities of some physicochemical parameters of Epie creek in the Niger- Delta. J. Appl. Sci. Environ. 5: 47-55.

[11]. Adekunle, I. M., Adetunji, M. T., Gbadebo A. M. and Banjoko O. B. (2007). Assessment of Groundwater Quality in a Typical Rural Settlement in Southwest Nigeria. Int. J. Environ. Res. Public Health, 4(4), 307-318.

[12]. Hati, S.S. Dimari, G.A. Waziri, M. and Pindiga, Y.N. (2008). Interaction Profile for $\mathrm{As}, \mathrm{Cd}, \mathrm{Cr}$ and $\mathrm{Pb}$ in surface water, superficial and background sediments of Lake Alau, Maiduguri-Nigeria. Terr. Aquatic Environ. Toxicol. CGlobal Science Books. 30-33.

[13]. Audu, A. A. and Lawal, A. O. (2005). Variation in Metal Contents of Plants in Vegetable Garden Sites in Kano Metropolis. J. Appl. Sci. Environ. Management 10: 105-109.

[14]. Konofal, E., Lecendreux, M., Arnulf, I. and Mouren, M.C. (2004). Iron deficiency in children with attention-deficit/hyperactivity disorder. Arch. Pediatr. Adolesc. Med. 158: 1113-1115.

[15]. Adebisi, A. (1981). The physic-chemical hydrology of a tropical seasonal river-upper Ogun river. Hydrobiological. 79, $157-165$.

[16]. De. A.K. (2002). Environmental Chemistry 4th Edition, New Age International Publishers, New Delhi, $245-252$.

[17]. Chov, V. T. (1964). Handbook of applied hydrology: A compendium of water resource technology. MacGraw-Hill, New York, USA.

[18]. Inoue, T. and Ebise, S. (1991). Runoff characteristics of COD, BOD, C, N and P loading from rivers to enclosed Coaster seas. Marine Pollution Bulletin. 23, 11-14.

[18]. Kocak, S., Tokusoglu, O. and Aycan, S. (2005). Some heavy metal and trace essential element detection in canned vegetable foodstuffs by differential pulse polarography (DPP), Electronic J. Environ. Agric. Food Chem. 4: 871-878.

[19]. Sharma, R.K., Agrawal, M., and Marshall, F. (2007). Heavy metal contamination of soil and vegetables in suburban areas of Varanasi, India. Ecotoxicol. Environ. Safety. J.

[20]. Kumar, M. (1998). Waste disposal systems in slaughter houses suitable for developing countries. FAO Report. Rome, Italy.

[21]. Bartram, J. and Balanc, R. (1996). Water quality monitoring: A practical guide to the design and implementation of fresh water quality studies and monitoring programmes. London, England.

[22]. APHA. (1998). Standard methods for the examination of water and wastewater. 18th Edition. American Public health Association, Washington, DC pp 45-60.

[23]. WHO (2004). Rolling revision of the WHO guidelines for drinking water quality, Draft for review and comments. World Health Organization, (WHO/SDE/WSH/04.08/56).

[24]. FEPA (Federal Environmental Protection Agency). (1991). Guidelines and Standards for Environmental Pollution Control in Nigeria. Pp. 54-58.

[25]. Chapman, D. (1997). Water Quality Assessment. A Guide to the use of Biota, Sediments and water in Environmental Monitoring. Second Edition. E \& FN Spon, London.

[26]. WQM Report. (1999). Annual report on water quality monitoring of upper and lower lakes Bhopal, Volumes I and II.

[27]. ICMR (1975). Manual of standard of quality for drinking water supplies Special report series No.44, 2nd edition.

[28]. APHA. (1999). Standard methods standard methods for the Examination of water and wastewater (20th Edition), American Water Works Association (AWWA) and Water Environment Federations. Washington. Pp. 1325. 